\title{
Penerapan Activity Based Costing System Dalam Penentuan Harga Pokok Produksi (Studi Kasus pada Industri Roti Cempaka Mulia)
}

\author{
Sri Dwiningsih \\ Program Studi Manajemen \\ Sekolah Tinggi Ilmu Ekonomi Kertanegara Malang \\ Sridwi76@yahoo.com
}

\begin{abstract}
Abstrak : Penentuan harga pokok produksi merupakan informasi penting bagi perusahaan untuk menetapkan harga jual produk. Dalam menentukan harga pokok produksi dapat dilakukan dengan beberapa metode yaitu cara konvensional dan metode activity based costing. Metode konvensional pada penentuan harga pokok produksi dianggap kurang tepat karena tidak melibatkan semua biaya overhead pabrik, sehingga dibutuhkan salah satu metode yang tepat yaitu sistem Activity Based Costing (ABC) yang dapat menentukan harga pokok produksi dengan lebih akurat. Karena sistem ini menelusuri biaya dalam setiap aktivitasnya dan menggunakan cost driver berdasarkan unit. Objek penelitian ini adalah biaya harga pokok produksi yang menjadi fokus dari aktivitas produksi roti pada Industri Roti Cempaka Mulia. Jenis penelitian ini adalah kuantitatif, yaitu penelitian yang tujuannya untuk mengungkapkan atau mengeksplore atau menjelaskan secara mendalam tentang variabel tertentu dan penelitian ini bersifat deskriptif, sehingga penelitian ini digunakan untuk mengkaji secara mendalam tentang penerapan sistem Activity Based Costing dalam penentuan harga pokok produksi pada Industri Roti Cempaka Mulia di Desa Baran Kecamatan Purwosari Kabupaten Pasuruan. Simpulan dari penelitian ini adalah sistem activity based costing dalam menentukan harga pokok produksi bakpia, roti manis dan brownies sudah sesuai karena pembagian biaya sudah jelas berdasarkan pemicu biaya dan sumber daya yang dikonsumsi masing-masing produk. Bagi peneliti lain yang akan melakukan penelitian sejenis dengan menggunakan subjek usaha kecil dan menengah, khususnya yang memproduksi produk lebih dari satu jenis produk. Peneliti selanjutnya diharapkan lebih komprehensip atau menyeluruh dalam mengkalkulasi biaya baik biaya produksi maupun biaya non produksi dan memperpanjang periode waktu penelitian, sehingga diperoleh hasil penelitian yang lebih akurat.
\end{abstract}

Kata kunci : biaya bahan baku, biaya tenaga kerja, biaya overhead pabrik

\section{Pendahuluan}

Dalam era globalisasi pada saat ini, kita dituntut untuk mampu memenuhi kebutuhan hidup yang semakin meningkat. Seiring dengan perkembangan teknologi dan informasi, banyak bermunculan usaha-usaha baik dalam bidang jasa maupun bidang produksi barang. Banyaknya industri yang terus bermunculan, maka timbul suatu persaingan di antara industri sejenis. Perusahaan-perusahaan atau industri- industri itu didirikan dan beroperasi, tentu memiliki suatu tujuan atau rencana yang akan dicapai. Dari sekian banyak tujuan tersebut, yang paling utama adalah mendapatkan keuntungan atau laba. Komponen pembentukan laba adalah pendapatan yang diperoleh dari hasil penjualan produksi dan jasa yang dihasilkan oleh perusahaan. Sedangkan biaya adalah pengorbanan yang harus dikeluarkan oleh perusahaan untuk memproduksi atau menghasilkan sesuatu barang atau jasa. Biaya tersebut disebut sebagai biaya 
harga pokok atau harga pokok produksi. Untuk menentukan besarnya biaya tersebut harus tepat dan akurat sehingga harga pokok produksi merupakan hal yang sangat penting mengingat manfaat informasi harga pokok produksi adalah untuk menentukan harga jual produk. Dalam menentukan harga pokok produksi, informasi yang dibutuhkan adalah informasi mengenai biaya bahan baku, biaya tenaga kerja, dan biaya overhead pabrik. Ketiga jenis biaya tersebut harus ditentukan secara cermat, baik dalam pencatatan maupun penggolongannya. Sehingga informasi harga pokok produksi yang dihasilkan dapat diandalkan baik untuk penetapan harga jual produk.

Harga pokok produksi sangat berpengaruh dalam perhitungan laba rugi perusahaan, apabila perusahaan kurang teliti atau salah dalam penentuan harga pokok produksi, akan mengakibatkan kesalahan dalam penentuan laba rugi yang diperoleh perusahaan. Selain harga pokok produksi yang berpengaruh terhadap perhitungan laba rugi perusahaan, pencapaian laba juga dapat dilakukan oleh perusahaan dengan berbagai cara antara lain penentuan harga jual. Industri Roti Cempaka Mulia yang berada di Desa Baran Kecamatan Purwosari - Pasuruan, Usaha ini bergerak di bidang produksi makanan yaitu produksi roti. Usaha ini didirikan oleh Ibu Hj. Wahyudi pada tahun 2010, dimana dalam operasinya usaha ini mempekerjakan 5 orang karyawan. Roti yang diproduksi yaitu bakpia, roti manis, dan brownies cempaka.

Peneliti akan menulusuri biaya - biaya apa saja yang telah dikeluarkan selama proses produksi roti produk Cempaka Mulia, yaitu dalam penelitian ini bakpia, brownies dan roti manis dalam menentukan berapa harga pokok dari produk tersebut dengan menggunakan metode Activity Based Costing (ABC). Alasan penggunaan metode Activity Based Costing (ABC) dalam penelitian ini yaitu karena konsep tersebut biaya yang dicatat dalam harga pokok produksi didasarkan pada aktivitas yang dilakukan, selain itu metode ini juga merupakan metode penentuan harga pokok yang diterima secara umum, sehingga memudahkan untuk pihak eksternal membaca laporan keuangan yang dibuat oleh perusahaan. Dengan penelitian ini penulis ingin menentukan harga pokok produksi yang merupakan hal yang sangat penting, karena harga pokok produksi dapat digunakan dalam pengambilan keputusan yang dilakukan oleh pemilik usaha Cempaka Mulia dalam menentukan harga jual produk. Selama ini pemilik usaha Cempaka Mulia telah melalukan perhitungan atas biaya produksi tetapi dalam membuat laporan harga pokok produksinya belum dapat menunjukkan harga pokok produksi yang tepat dan benar sesuai dengan pengumpulan biaya produksinya. Selain itu peneliti juga ingin mengetahui adanya pengaruh inflasi yang juga sangat berpengaruh terhadap harga pokok produksi karena jika terdapat inflasi, juga akan menyulitkan pemilik usaha dalam menghitung harga pokok produksi. Persentase kenaikan inflasi sering tidak teratur. Akibatnya, penghitungan harga pokok menjadi tidak tepat.

\section{A. Harga Pokok Produksi}

Menurut Hansen dan Mowen (2009:60) menyatakan harga pokok produksi (cost of goods manufactured) mencerminkan total biaya barang yang diselesaikan selama periode berjalan.

Harga pokok produksi menurut Mulyadi (1999:71) memiliki fungsi yang cukup penting yaitu diantaranya :

1. Harga pokok sebagai penetapan harga jual

Harga pokok merupakan hal penting yang perlu diketahui oleh perusahaan karena harga pokok dapat memberikan pengaruh terhadap penentuan harga jual produk tertentu.

2. Harga pokok sebagai dasar penetapan laba

Apabila perusahaan telah membuat perhitungan harga pokok maka perusahaan dapat menetapkan laba yang diharapkan yang akan mempengaruhi tingkat harga jual suatu produk tertentu.

3. Harga pokok sebagai dasar penilaian efisiensi 
Harga pokok dapat dijadikan dasar untuk mengontrol pemakaian bahan, gaji dan biaya produksi tidak langsung.

B. Sistem Activity Based Costing (ABC)

Perhitungan biaya berdasarkan aktivitas (Activity Based Costing - ABC) menurut Mulyadi (2003: 53) adalah sistem informasi biaya berbasis aktivitas yang didesain untuk memotivasi personel dalam melakukan pengurangan biaya dalam jangka panjang melalui pengelolaan aktivitas.

Sedangkan perhitungan biaya berdasarkan aktivitas - Activity Based Costing (ABC) menurut Garrison et.al (2006: 440) adalah metode perhitungan biaya (costing) yang dirancang untuk menyediakan informasi biaya bagi manajer untuk keputusan strategis dan keputusan lainnya yang mungkin akan mempengaruhi kapasitas dan juga biaya tetap.

C. Manfaat Sistem Activity Based Costing (ABC)

Manfaat utama sistem perhitungan biaya berdasarkan aktivitas menurut Blocher et.al (2007: 232) adalah :

1. Pengukuran profitabilitas yang lebih baik

Activity Based Costing (ABC) menyajikan biaya produk yang lebih akurat dan informatif, mengarahkan pada pengukuran profitabilitas produk yang lebih akurat dan keputusan strategis yang diinformasikan dengan lebih baik tentang penetapan harga jual, lini produk dan segmen pasar.

2. Keputusan dan kendali yang lebih baik

Activity Based Costing (ABC) menyajikan pengukuran yang lebih akurat tentang biaya yang timbul karena dipicu oleh aktivitas, membantu manajemen untuk meningkatkan nilai produk dan nilai proses dengan membuat keputusan yang slebih baik tentang desain produk, mengendalikan biaya secara lebih baik dan membantu perkembangan proyek-proyek yang meningkatkan nilai.

3. Informasi yang lebih baik untuk mengendalikan biaya kapasitas

Activity Based Costing (ABC) membantu manajer mengidentifikasi dan mengendalikan biaya kapasitas yang tidak terpakai.

\section{Metode}

A. Metode Penelitian

Penelitian ini menggunakan metode kuantitatif melalui eksplanatory research, yaitu penelitian yang tujuannya untuk mengungkapkan atau mengexplore atau menjelaskan secara mendalam tentang variabel tertentu dan penelitian ini bersifat deskriptif (Arikunto, 2006: 14). Penelitian yang akan dilakukan ini terkait mengenai penelusuran biaya-biaya produksi yang dikeluarkan selama proses produksi untuk menentukan harga pokok produksi dari produk Cempaka Mulia yaitu bakpia, roti manis dan brownies berdasarkan metode Activity Based Costing (ABC). Penelitian dilaksanakan di Industri Roti Cempaka Mulia yaitu di rumah Bu Hj. Wahyudi yang terletak di Desa Baran Kecamatan Purwosari Kabupaten Pasuruan. Waktu yang di gunakan peneliti yaitu pada bulan Desember 2016 - Januari 2017. Variabel penelitian ini adalah biaya-biaya yang menjadi fokus dari aktivitas dalam pembuatan roti antara lain biaya bahan baku, biaya tenaga kerja, dan biaya overhead pabrik.

1. Biaya Bahan Baku

Bahan baku adalah keseluruhan bahan utama untuk pembuatan produk jadi. Pengertian bahan baku dapat meluas meliputi juga bahan - bahan yang digunakan untuk memperlancar proses produksi. Bahan baku yang demikian termasuk dalam bahan penolong atau bahan pembantu. 
2. Biaya Tenaga Kerja

Tenaga kerja ada dua yaitu tenaga kerja langsung dan tenaga kerja tidak langsung. Biaya tenaga kerja tidak langsung merupakan salah satu unsur biaya overhead pabrik. Biaya tenaga kerja disini adalah jumlah biaya keseluruhan yang dibayarkan untuk karyawan yang merupakan tenaga kerja dalam pembuatan roti. Tenaga kerja yang dipekerjakan pada Cempaka Mulia ini berjumlah 5 orang.

3. Biaya Overhead Pabrik

Biaya overhead pabrik menurut Mulyadi (1999: 208) adalah biaya produksi selain biaya bahan baku dan biaya tenaga kerja langsung. Pengalokasian biaya overhead pabrik yang lebih akurat dengan menggunakan sistem activity based costing, karena dapat menelusuri biaya sesuai dengan aktivitas yang dilakukan untuk membuat suatu produk tertentu. Biaya overhead pabrik yang ada di industri roti Cempaka Mulia antara lain biaya bahan pembantu, biaya tenaga kerja tidak langsung, biaya listrik, biaya telepon, dan biaya air minum.

B. Tahapan Penelitian

Pada tahap pertama hal-hal yang perlu dilakukan adalah :

a. Mengidentifikasi aktivitas

b. Membebankan biaya ke aktivitas

c. Mengelompokkan aktivitas yang berkaitan untuk membentuk kumpulan yang sejenis (homogen) kemudian mengelompokkan biaya aktivitas yang telah dikelompokkan untuk mendefinisikan kelompok biaya sejenis (homogeneous cost pool)

d. Menghitung tarif kelompok

e.

$$
\text { Tarif pool }=\frac{\text { BOP Kelompok aktivitas tertentu }}{\text { Driver Biayanya }}
$$

Supriyono (2007 : 271)

Biaya Overhead Pabrik (BOP) setiap kelompok aktivitas dilacak ke berbagai jenis produk dengan menggunakan tarif kelompok yang dikonsumsi oleh setiap produk. Pembebanan BOP pada produk dihitung dengan rumus sebagai berikut :

Biaya Overhead Pabrik (BOP) dibebankan $=$ Tarif kelompok $\mathrm{x}$ Unit cost driver

Supriyono $(2007: 272)$

III. Hasil dan Pembahasan

Tabel 1

Data Penjualan Roti Cempaka Mulia November 2016

\begin{tabular}{|c|l|c|}
\hline No & \multicolumn{1}{|c|}{ Jenis Roti } & Jumlah (Box) \\
\hline 1 & Bakpia & 3.500 \\
\hline 2 & Roti Manis & 6.000 \\
\hline 3 & Brownies & 5.000 \\
\hline & Jumlah & 14.500 \\
\hline
\end{tabular}

Sumber : Data Industri Roti Cempaka Mulia bulan November 2016 
Jumlah tenaga kerja yang langsung berkaitan dengan produksi adalah sebanyak 4 orang dan tenaga kerja yang tidak berkaitan langsung dengan produksi ada satu orang yaitu bagian pengiriman. Biaya tenaga kerja langsung selama satu bulan dibayar sebesar Rp. 400.000,- sedangkan untuk tenaga pengiriman sebesar Rp 700.000 termasuk biaya BBM.

Dalam tabel berikut menjelaskan bahan baku yang dikeluarkan selama bulan November 2016.

Tabel 2

Biaya Bahan Baku Roti Cempaka Mulia November 2016

\begin{tabular}{|c|c|c|c|c|c|c|c|c|c|c|}
\hline \multirow{2}{*}{ No. } & \multirow{2}{*}{ Bahan Baku } & \multicolumn{2}{|c|}{$\begin{array}{l}\text { Tepung } \\
\text { Terigu }\end{array}$} & \multicolumn{2}{|c|}{$\begin{array}{c}\text { Kacang } \\
\text { Hijau }\end{array}$} & \multicolumn{2}{|c|}{ Mentega } & \multicolumn{2}{|c|}{ Gula } & \multirow{2}{*}{$\begin{array}{c}\text { Total Biaya } \\
\text { (Rp) }\end{array}$} \\
\hline & & Kg & $\begin{array}{c}\text { Harga } \\
\text { (Rp) }\end{array}$ & Kg & $\begin{array}{c}\text { Harga } \\
\text { (Rp) }\end{array}$ & Kg & $\begin{array}{r}\text { Harga } \\
\text { (Rp) }\end{array}$ & Kg & $\begin{array}{c}\text { Harga } \\
\text { (Rp) }\end{array}$ & \\
\hline 1 & Bakpia & 500 & 7.500 & 88 & 7.500 & - & - & - & - & 4.410 .000 \\
\hline 2 & Roti Manis & 1.250 & 7.500 & - & - & 300 & 26.000 & 750 & 12.000 & 26.175 .000 \\
\hline 3 & Brownies & 750 & 7.500 & & & 350 & 26.000 & 750 & 12.000 & 23.725 .000 \\
\hline & Jumlah & 2.500 & & & & & & & & 54.310 .000 \\
\hline
\end{tabular}

Sumber : Data Industri Roti Cempaka Mulia bulan November 2016

A. Penerapan Activity Based Costing System Dalam Penentuan Harga Pokok Produksi Bakpia

Analisis penentuan harga pokok produksi yang lebih akurat dapat dilakukan dengan menggunakan sistem activity based costing. Perhitungan harga pokok produksi pada Industri Roti Cempaka Mulia dengan sistem activity based costing dibagi dalam tiga cost pool. Cost pool tersebut yaitu Bakpia, Roti Manis, dan Brownies. Aktivitas yang terjadi dalam pembuatan roti dikelompokkan dalam 7 cost driver yaitu pembuatan adonan, pemanggangan,, pencetakan, pengemasan, pengiriman, penerangan dan pemeliharaan.

Tabel 3

Penentuan HPP Bakpia berdasarkan Sistem ABC

\begin{tabular}{|c|c|c|c|c|c|c|c|c|c|}
\hline Jml & \multicolumn{2}{|c|}{ BBB } & \multicolumn{2}{|c|}{ BTK } & \multicolumn{2}{|c|}{ BOP } & \multicolumn{2}{|c|}{ Total HPP } & \multirow{2}{*}{$\begin{array}{c}\text { HPP/ } \\
\text { Box } \\
\text { (Rp) }\end{array}$} \\
\hline Box & $\mathbf{R p}$ & $\%$ & $\mathbf{R p}$ & $\%$ & $\mathbf{R p}$ & $\%$ & $\mathbf{R p}$ & $\%$ & \\
\hline 3.500 & 4.410 .000 & 60 & 1.600 .000 & 22 & 1.383 .611 & 18 & $7,393,611$ & 100 & 2.112 \\
\hline
\end{tabular}

Sumber : Data Industri Roti Cempaka Mulia bulan November 2016 
Pada tabel diatas menyajikan penentuan harga pokok produksi bakpia berdasarkan sistem activity base costing. Harga pokok produksi bakpia diperoleh dari 3 unsur biaya yaitu, biaya bahan baku ditambah biaya tenaga kerja dan ditambah biaya overhead pabrik.

Dari perhitungan biaya pada masing - masing aktifitas pada pembuatan bakpia, maka kelompok biaya pada bakpia bisa dilihat pada tabel berkut :

\section{Tabel 4}

\section{Hasil Perhitungan HPP bakpia}

\begin{tabular}{|c|c|c|c|c|c|c|c|}
\hline No & Kelompok Aktifitas & Jenis Biaya & $\begin{array}{c}\text { Total Biaya } \\
\text { (Rp) }\end{array}$ & $\begin{array}{l}\text { Penyebab } \\
\text { Biaya }\end{array}$ & Tarif & $\begin{array}{c}\text { Unit } \\
\text { Driver }\end{array}$ & $\begin{array}{l}\text { Total } \\
\text { (Rp) }\end{array}$ \\
\hline \multirow[t]{4}{*}{1} & Pembuatan Adonan & Telepon & 200.000 & & & & \\
\hline & & Bahan Pembantu & 3.221 .100 & & & & \\
\hline & & Air Minum & 20.000 & & & & \\
\hline & Pemb adonan Total & & 3.441 .100 & 2.500 & 1.376 & 500 & 688.220 \\
\hline \multirow[t]{2}{*}{2} & Pencetakan & Air Minum & 20.000 & & & & \\
\hline & Pencetakan Total & & 20.000 & 2.500 & 8 & 500 & 4.000 \\
\hline \multirow[t]{3}{*}{3} & Pemanggangan & Bahan Bakar Gas & 532.000 & & & & \\
\hline & & Air Minum & 20.000 & & & & \\
\hline & $\begin{array}{l}\text { Pemanggangan } \\
\text { Total }\end{array}$ & & 552.000 & 2.500 & 221 & 500 & 110.400 \\
\hline \multirow[t]{3}{*}{4} & Pengemasan & Kemasan & 1.050 .000 & & & & \\
\hline & & Air Minum & 20.000 & & & & \\
\hline & Pengemasan Total & & 1.070 .000 & 14.500 & 74 & 3.500 & 258.276 \\
\hline \multirow[t]{3}{*}{5} & Pengiriman & BTKTL & 400.000 & & & & \\
\hline & & Solar & 300.000 & & & & \\
\hline & Pengiriman Total & & 700.000 & 14.500 & 48 & 3.500 & 168.966 \\
\hline \multirow[t]{2}{*}{6} & Penerangan & Listrik & 250.000 & & & & \\
\hline & Penerangan Total & & 250.000 & 150 & 1.667 & 36 & 60.000 \\
\hline \multirow[t]{3}{*}{7} & Pemeliharaan & $\begin{array}{l}\text { Perawatan } \\
\text { peralatan }\end{array}$ & 250.000 & & & & \\
\hline & Pemeliharaan Total & & 250.000 & 208 & 1.202 & 78 & 93.750 \\
\hline & Jumlah & & 6.283 .100 & & & & 1.383 .611 \\
\hline
\end{tabular}

Sumber : Data primer yang diolah bulan November 2016 
B. Harga Pokok Produksi Bakpia Berdasarkan Sistem Konvensional

Penentuan harga pokok produksi bakpia dengan sistem konvensional terutama dalam perhitungan biaya overhead pabrik tidak dihitung secara detail berdasarkan atas pemicu biaya dan sumber daya yang dikonsumsi oleh produk bakpia, karena harga pokok produksi dihitung dengan cara menjumlahkan biaya bahan baku, biaya tenaga kerja, dan biaya overhead.

Industri Roti Cempaka Mulia menentukan harga pokok produksi masih menggunakan sistem konvensional, berikut ini adalah penentuan harga pokok produksi berdasarkan sistem konvensional :

$$
\begin{aligned}
& \mathrm{BOP}=\frac{\text { Biaya overhead pabrik yang dianggarkan }}{\text { Jumlah produksi }} \\
& \mathrm{BOP}=\frac{\mathrm{Rp} 6.283 .100,-}{14.500 \mathrm{Box}}=433 / \mathrm{box}
\end{aligned}
$$

Penentuan tarif biaya overhead pabrik bakpia dengan sistem konvensional pada Industri Roti Cempaka Mulia dapat dilihat pada tabel:

Tabel 5

Penentuan tarif BOP bakpia dengan sistem konvensional

\begin{tabular}{|l|c|c|}
\hline Jumlah Box & Tarif Biaya overhead (Rp) & BOP bakpia/box (Rp) \\
\hline 3.500 & 433 & 1.515 .500 \\
\hline \multicolumn{2}{|c|}{ Jumlah } & 1.515 .500 \\
\hline
\end{tabular}

Sumber : Data Industri Roti Cempaka Mulia bulan November 2016

Setelah biaya overhead diketahui, maka penentuan harga pokok produksi dengan sistem konvensional dapat dilakukan. Penentuan harga pokok produksi bakpia berdasarkan sistem konvensional dapat dilihat pada tabel diatas

Tabel 6

Penentuan HPP Bakpia berdasarkan sistem konvensional

\begin{tabular}{|c|c|c|c|c|c|c|c|c|c|}
\hline Jumlah & \multicolumn{2}{|c|}{ BBB } & \multicolumn{2}{c|}{ BTK } & \multicolumn{2}{c|}{ BOP } & \multicolumn{2}{c|}{ Total HPP } & HPP/ \\
\cline { 1 - 7 } Box & Rp & $\%$ & Rp & \% & Rp & \% & Rp & $\%$ & Box \\
\hline 3.500 & 4.410 .000 & 59 & 1.600 .000 & 21,2 & 1.515 .500 & 20,1 & 7.525 .500 & 100 & 2.150 \\
\hline
\end{tabular}

Sumber : Data Industri Roti Cempaka Mulia bulan November 2016 
Tabel diatas menunjukkan penentuan harga pokok produksi bakpia berdasarkan sistem konvensional. Harga pokok produksi diperoleh dari penjumlahan 3 unsur biaya yaitu, biaya bahan baku, biaya tenaga kerja, dan biaya overhead pabrik.

C. Perbandingan Harga Pokok Produksi Bakpia Berdasarkan Sistem Activity Based Costing Dengan Sistem Konvensional. Penentuan harga okok produksi bakpia berdasarkan sistem ABC dengan sistem konvensional terdapat perbedaan pada biaya overhead pabrik. Perbedaan tersebut dapat dilihat pada tabel dibawah ini.

Tabel 7

Perbandingan penentuan HPP bakpia berdasarkan sistem ABC dengan sistem Konvensional

\begin{tabular}{|c|l|r|r|}
\hline Jumlah Produk & \multicolumn{1}{|c|}{ Perhitungan HPP } & HPP (Rp) & \multicolumn{1}{c|}{ HPP/Box } \\
\hline 3.500 & Activity Based Costing & 7.393 .611 & 2.112 \\
\hline 3.500 & Konvensional & 7.525 .500 & 2.150 \\
\hline Selisih & & -131.889 & -38 \\
\hline
\end{tabular}

Sumber : Data Industri Roti Cempaka Mulia bulan November 2016

Berdasarkan tabel diatas menunjukkan bahwa harga pokok produksi bakpia dengan sistem konvensional menghasilkan harga pokok produksi lebih besar dibandingkan dengan harga pokok produksi menggunakan sistem activity based costing. Perbedaan yang terjadi antara harga pokok produksi menggunakan sistem konvensional dan sistem activity based costing disebabkan karena pembebanan overhead pada masing - masing produk. Pada sistem konvensional biaya produksi overhead pabrik hanya dibebankan pada satu cost driver saja. Sedangkan pada sistem activity based costing, biaya overhead pada masing - masing produk dibebankan pada banyak cost driver sesuai aktifitas - aktifitas yang dilakukan dalam pembuatan bakpia. Sehingga dalam sistem activity based costing mampu mengalokasikan biaya aktifitas ke setiap produk lebih akurat berdasarkan konsumsi masing - masing aktifitas.

\section{Perhitungan Harga Pokok Produksi Setelah Inflasi pada Bakpia}

Dalam sebuah perusahaan tentunya ingin mencapai laba yang maksimal. Selain menentukan harga pokok produksi, sebuah perusahaan juga memperhatikan tingkat inflasi. Menurut Peraturan Menteri Keuangan (PMK) Nomor 93.PMK.011/2014 tentang inflasi. Untuk tahun 2017, sasaran inflasi ditetapkan pada tingkat 4\% persen. Maka bisa kita tentukan harga pokok produksi bakpia setelah inflasi sebagai berikut :

$$
\begin{aligned}
& =104 \% \text { x HPP Bakpia } \\
& =104 \% \times 2.112=2.196 / \mathrm{Box}
\end{aligned}
$$


E-ISSN (Online) : $2621-3230$

Jurnal Aplikasi Manajemen dan Inovasi Bisnis Volume 1, Nomor 1, Agustus 2018

Dengan perhitungan di atas, kita bisa mengetahui harga pokok produksi setelah inflasi untuk bakpia adalah 2.196/Box lebih besar daripada harga pokok produksi sebelum inflasi yang

\begin{tabular}{|c|l|r|r|r|}
\hline No. & \multicolumn{1}{|c|}{ Kelompok Biaya } & Bakpia (Rp) & \multicolumn{1}{c|}{ Roti Manis (Rp) } & \multicolumn{1}{c|}{ Brownies (Rp) } \\
\hline 1 & Pembuatan Adonan & 688.220 & 2.877 .000 & 2.082 .000 \\
\hline 2 & Pencetakan & 4.000 & 10.000 & 6.000 \\
\hline 3 & Pemanggangan & 110.400 & 314.000 & 177.000 \\
\hline 4 & Pengemasan & 258.276 & 1.249 .655 & 868.966 \\
\hline 5 & Pengiriman & 168.966 & 289.655 & 241.379 \\
\hline 6 & Penerangan & 60.000 & 103.333 & 86.667 \\
\hline 7 & Pemeliharaan & 93.750 & 78.125 & 78.125 \\
\hline & Jumlah & $\mathbf{1 . 3 8 3 . 6 1 1}$ & $\mathbf{4 . 9 2 1 . 7 6 9}$ & $\mathbf{3 . 5 4 0 . 1 3 6}$ \\
\hline
\end{tabular}

Sumber : Data Industri Roti Cempaka Mulia bulan November 2016

1. Harga Pokok Produksi ABC System

\begin{tabular}{|l|c|c|c|c|}
\hline \multicolumn{1}{|c|}{ Jenis } & BBB (Rp) & BTK (Rp) & BOP (Rp) & HPP (Rp) \\
\hline Bakpia & 4.410 .000 & 1.600 .000 & 1.383 .611 & 7.393 .611 \\
\hline Roti Manis & 26.175 .000 & 1.600 .000 & 4.921 .769 & 32.696 .769 \\
\hline Brownies & 23.725 .000 & 1.600 .000 & 3.540 .136 & 28.865 .136 \\
\hline
\end{tabular}

Sumber : Data Industri Roti Cempaka Mulia bulan November 2016

2. Harga Pokok Produksi Sistem Konvensional

\begin{tabular}{|l|c|c|c|c|}
\hline \multicolumn{1}{|c|}{ Jenis } & BBB (Rp) & BTK (Rp) & BOP (Rp) & HPP (Rp) \\
\hline Bakpia & 4.410 .000 & 1.600 .000 & 1.515 .500 & 7.525 .500 \\
\hline Roti Manis & 26.175 .000 & 1.600 .000 & 4.395 .310 & 32.170 .310 \\
\hline Brownies & 23.725 .000 & 1.600 .000 & 3.885 .000 & 29.210 .000 \\
\hline
\end{tabular}

Sumber : Data Industri Roti Cempaka Mulia bulan November 2016

3. Perbandingan HPP ABC System dengan Sistem Konvensional

\begin{tabular}{|l|c|c|c|}
\hline \multirow{2}{*}{ Jenis } & \multicolumn{2}{|c|}{ HPP (Rp) } & \multirow{2}{*}{ Selisih (Rp) } \\
\cline { 2 - 3 } & ABC & Konvensional & \\
\hline Bakpia & 7.393 .611 & 7.525 .500 & -131.889 \\
\hline Roti Manis & 32.696 .769 & 32.170 .310 & 526.459 \\
\hline Brownies & 28.865 .136 & 29.210 .000 & -344.864 \\
\hline
\end{tabular}

Sumber : Data Industri Roti Cempaka Mulia bulan November 2016 


\section{Kesimpulan}

Berdasarkan hasil penelitian dan pembahasan pada penelitian ini, maka selanjutnya dapat disimpulkan bahwa penentuan harga pokok produksi untuk bakpia pada Industri Roti Cempaka Mulia berdasarkan sistem activity based costing lebih kecil dan akurat dibandingkan dengan sistem konvensional. Harga pokok produksi cost pool Bakpia dengan menggunakan sistem activity based costing sebesar Rp 7.393.611 sedangkan jika menggunakan sistem konvensional harga pokok produksi untuk cost pool bakpia adalah sebesar Rp 7.525.500 atau selisih sebesar Rp 131.889. Perbedaaan yang terjadi antara harga pokok produksi menggunakan sistem activity based costing dan konvensional disebabkan karena pembebanan overhead pada masing - masing produk. Sedangkan harga pokok produksi setelah inflasi adalah 2.196/Box lebih besar daripada harga pokok produksi sebelum inflasi yang menggunakan sistem activity based costing.

Penentuan harga pokok produksi untuk roti manis pada Industri Roti Cempaka Mulia berdasarkan sistem activity based costing lebih besar dan akurat dibandingkan dengan sistem konvensional. Harga pokok produksi cost pool Bakpia dengan menggunakan sistem activity based costing sebesar Rp 32.696.769 sedangkan jika menggunakan sistem konvensional harga pokok produksi untuk cost pool roti manis adalah sebesar Rp 32.170.310 atau selisih sebesar Rp 526.458. Perbedaaan yang terjadi antara harga pokok produksi menggunakan sistem activity based costing dan konvensional disebabkan karena pembebanan overhead pada masing- masing produk. Sedangkan harga pokok produksi setelah inflasi adalah 5.667/Box lebih besar daripada harga pokok produksi sebelum inflasi yang menggunakan sistem activity based costing.

Penentuan harga pokok produksi untuk brownies pada Industri Roti Cempaka Mulia berdasarkan sistem activity based costing lebih kecil dan akurat dibandingkan dengan sistem konvensional. Harga pokok produksi cost pool brownies dengan menggunakan sistem activity based costing sebesar Rp 28.865.136 sedangkan jika menggunakan sistem konvensional harga pokok produksi untuk cost pool roti manis adalah sebesar Rp 29.210.000 atau selisih sebesar Rp 344.864 . Perbedaaan yang terjadi antara harga pokok produksi menggunakan sistem activity based costing dan konvensional disebabkan karena pembebanan overhead pada masing - masing produk. Sedangkan harga pokok produksi setelah inflasi adalah 6.004/Box lebih besar daripada harga pokok produksi sebelum inflasi yang menggunakan sistem activity based costing.

\section{Saran}

Berdasarkan simpulan dari hasil penelitian diatas, maka peneliti menyarankan sebagai berikut :

1. Bagi Industri Roti Cempaka Mulia agar dapat melakukan perhitungan harga pokok produksi yang tepat, perusahaan harus mengadakan pengelompokkan atau pengklasifikasian biaya agar biaya-biaya yang dikeluarkan oleh perusahaan dapat dibebankan dengan tepat sehingga perusahaan dapat menentukan harga jual produknya secara wajar, sehingga produk yang 
dihasilkan perusahaan dapat bersaing di pasar. Tingkat inflasi juga perlu diperhatikan karena juga sangat berpengaruh terhadap pengadaan harga pokok produksi.

2. Penelitian selanjutnya diharapkan lebih komprehensip atau menyeluruh dalam mengkalkulasi biaya baik biaya produksi maupun biaya non produksi sehingga diperoleh hasil penelitian yang lebih akurat.

\section{Daftar Pustaka}

Arikunto, Suharsimi. 2006. Prosedur Penelitian Suatu Pendekatan Praktik. Jakarta: PT RINEKA CIPTA

Blocher, Edward J. 2007. Cost Management. Manajemen Biaya Penekanan Strategis. Jakarta: Salemba Empat

Garrison, Ray H. Garrison, Eric W. Norren dan Peter C. Brewer. 2006. Akuntansi Manajerial. Jakarta: Salemba Empat

Hansen, Don R. dan Maryanne M. Mowen. 2006. Management Accounting. Jakarta: Salemba Empat 2009. Managerial Accounting. Akuntansi Managerial.Jakarta: Salemba Empat.

Horngren, Charles T., Srikant M. Datar, dan George Foster. 2005. Akuntansi Biaya Penekanan Manajerial. Jakarta: PT. INDEKS Kelompok GRAMEDIA

Mulyadi. 1999. Akuntansi Biaya. Yogyakarta: Adity Media 2003. Activity Based Cost System. Yogyakarta: UPP AMP YKPN

Nopirin. 1987. Ekonomi moneter, buku II . Yogyakarta: BPFE-UGM

Simamora, Henry. 2000. Akuntansi. Jakarta: Salemba Empat

Slamet, Achmad. 2007. Penganggaran. Perencanaan \& Pengendalian Usaha. Semarang: UNNES Press

Sugiyono. 2008. Metode Penelitian Kuantitatif, kualitatif dan R\&D. Bandung: Alfabeta

Sulistianingsih. 1999. Akuntansi Biaya. Yogyakarta: UPP AMP YKPN

Supriyono, R.A. 2007. Manajemen Biaya. Suatu Reformasi Pengelolaan Bisnis. Yogyakarta: BPFE 